36. Liakhoúski Ul., Mikhnik Ul., Hes' A. (2001). Slutski zbrojny chyn 1920 h. u dakumentakh i úspaminakh [Slutsk uprising in 1920 in the documents and memoirs]. Minsk: "Entsyklapedyks". 274 p. (in Belarusian).

37. Stashkevich N. S. (1985). Pryhovor revoliutsyy: Krushenie antysovetskoho dvizhenyia v Belorussii (19171925) [The verdict of the revolution: The collapse of the anti-Soviet movement in Belarus (1917-1925)]. Minsk: Unyversytetskoe. 304 p. (in Russian).

38. Stuzhynskaia N. (2009). Iz istoryi belorusskoj konspyratsyi: "Zelionyj Dub" [From the history of the Belarusian conspiracy: "Green Oak"]. Partyzanskaia i povstancheskaia bor'ba: opyt i uroky XX st.: Doklady akademii voennykh nauk: Voennaia istoryia. Saratov. № 3. P. 59-63. (in Russian).

39. Stuzhynskaia N. (2012). Belarus' miatsezhnaia. Z historyi úzbroenaha antysavetskaha supratsivu w 20-ia hady XX st. [Belarus is rebellious. From the history of armed anti-Soviet resistance in the 1920s.]. Minsk: Varaksin A. M. 362 p. (in Belarusian).

DOI: https:// doi.org/10.17721/2520-2626/2021.28.16 УДК 811. 161.2 (92) «19» Рудницький Я.
40. Stuzhynskaia N. I. (1995). "Zialiony Dub" ["Green Oak"]. Belaruski histarychny chasopis [Belarusian Historical Journal]. № 1. P. 57-64. (in Belarusian).

41. Stuzhynskaia N. (2014). Terytoryia atamana Shawchenki: pra mahilioúskaha paústantsa, iakomu sialiane "klanialisia iak kumiru» [Ataman Shevchenko's territory: about the Mogilev insurgent to whom peasants "bowed as an idol"]. URL: http://nn.by/?c=ar\&i=133013 (in Belarusian).

42. Khokhlov A. H. (1981). Krakh antysovetskoho bandytyzma $v$ Belorussyi v 1918-1925 hh. [The collapse of anti-Soviet banditry in Belarus in 1918-1925]. Minsk: Belarus'. 173 p. (in Russian).

\title{
Наталія Солонська
}

кандидат історичних наук, старший науковий співробітник

Відділу зарубіжної україніки Інституту книгознавства Національної бібліотеки України імені В. І. Вернадського;

ORCID: 0000-003-1444-9354

Email: solonska.n@ukr.net,

Галина Борисович провідний бібліотекар

Відділу зарубіжної україніки Інституту книгознавства Національної бібліотеки України імені В. І. Вернадського

Email:vzunbuv@ukr.net

\section{ПОЗИЦІЯ КАНАДСЬКО-УКРАЇНСЬКОГО ВЧЕНОГО ЯРОСЛАВА РУДНИЦЬКОГО У ВИРІШЕННІ МОВНОГО КОНФЛІКТУ В ІММІГРАЦІї}

\footnotetext{
Анотація. У статmі проаналізовано одну з проблем відносин особистості, що належить до етнічної меншості, до імміграційної спільноти, й англо- та фрранкомовної більшості країни нового проживання переселенців. Висвітлено проблему збереження національної ідентичності українців канадської діаспори через призму наполегливих, послідовних і толерантних кроків, здійснених відомим канадсько-українським мовознавцем, фольклористом, славістом, бібліотекознавцем, організатором науки, педагогом, громадським діячем, професором Я. Рудницьким у протистоянні мовній асиміляції власного народу; принциповість ученого у розв'язанні лінгвістичного конфлікту, що дало позитивне вирішення для обох сторін - Канади та української діаспори. Відбито вагомість громадянської позиції й значні потенційні можливості впливу на офріційні кола країни, урядові комісії, комітети, міжнародні організації та суспільну думку авторитетної в суспільстві та наукових колах людини розумової праці, яка, залучаючи історично обгрунтовані докази, доводить об`єктивність власної точки зору і в такий спосіб захищає національне достоїнство свого народу, його давню та багату культуру й відстоює свої моральні принципи переконання. Здійснено бібліографрічний огляд мовознавчих праць Я. Рудницького, де ним на підставі історично виважених фрактів, історико-політологічного, мовного аналізу досліджено сутність мовної асиміляції, що дорівнює знищенню національної окремішності. Показано, що лексикографрічні роботи, висновки з них дали вченому підгрунтя перемогти в боротьбі за Конституційне визнання української мови в Канаді, чим було підтримано політику офріційних мов і багатокультурності в країні. Підкреслено, що наукові
} 
висновки дали можливість ученому узагальнити та підсумувати дослідження і стало підставою для введення у широкий суспільний обіг місткої дефрініції - лінгвоцид (мововбивство), яка нині повсюдно застосовується в наукових працях.

Ключові слова: мовний конфлікт, мовна асиміляція; лінгвоцид (мововбивство); українці канадської діаспори, національна ідентичність.

\author{
Natalia Solonska \\ Candidate of Historical Sciences, Senior Research Fellow, \\ Department of Foreign Ukraine, Institute of Bibliology \\ V. I. Vernadsky National Library of Ukraine;
}

\begin{abstract}
Galina Borysovych
Leading Librarian of the Department of Foreign Ukrainian, Institute of Bibliology of the National Library of Ukraine named after V. I. Vernadsky
\end{abstract}

\title{
POSITION OF THE UKRAINIAN-CANADIAN SCIENTIST JAROSLAV RUDNYTSKYJ IN THE SETTELMENT OF THE LANGUAGE CONFLICT OF IMMIGRANTS
}

\begin{abstract}
The article analyzes one of the problems of personal relations belonging to the ethnic minority of the immigration community and the English-and French-speaking majority of the elite nation of the country of new immigrants, highlights the problem of preserving the national identity of Ukrainians in the Canadian diaspora through persistent, consistent and tolerant steps. Ukrainian linguist, folklorist, Slavist, librarian, organizer of science, teacher, public figure, Professor J. Rudnytsky in opposition to the linguistic assimilation of his own people; the principledness of the scientist in resolving the linguistic conflict, which gave a positive solution for both parties - Canada and the Ukrainian diaspora. The importance of the civic position and significant potential opportunities to influence the official circles of the country, government commissions, committees, international organizations and public opinion of authoritative intellectual work in society and academia, which, using historically sound evidence, proves the objectivity of his point of view. in this way he protects the national dignity of his people, their ancient and rich culture and defends his moral principles and beliefs. A bibliographic review of J. Rudnytsky's scientific work was carried out, where on the basis of historically balanced facts, historical-political, linguistic analysis he investigated the essence of language assimilation, which is equal to the destruction of national identity. It is shown that lexicographical works, conclusions from them gave the scientist a basis to win the struggle for the Constitutional recognition of the Ukrainian language in Canada, which supported the policy of official languages and multiculturalism in the country. It is emphasized that scientific conclusions gave the scientist the opportunity to summarize and summarize the research and became the basis for the introduction into public circulation of a capacious definition - linguocide (language murder), which is now widely used in scientific works.
\end{abstract}

Keywords: ethnolinguistic conflict, language assimilation; linguocide (language murder); Ukrainians of the Canadian Diaspora, national identity.

Постановка проблеми. Сьогоднішній світ характеризується явищем неспинного переміщення із країни в країну людей, які з різних причин шукають іншої долі на чужій землі. Імміграція вже має свою історію та достеменно вивчається цілим рядом наукових дисциплін. Історіографрія цієї загальноцивілізаційної проблеми колосальна. Основоположними працями історії канадських українців та імміграції українців у Канаді $€$ науковий доробок М. Боровика, Р. Климаша, М. Марунчака, Я. Рудницького та ін. Зріс відсоток праць, де аналізується проблема мовної асиміляції українців Канади.

Мета пропонованої статті - висвітлити проблему протистояння мовній асиміляції діаспори через призму наполегливих, послідовних і толерантних, науково обґрунтованих зусиль, здійснених визначним канадсько-українським ученим і громадським діячем Я. Рудницьким, розв язання ним об єктивно неминучого конфлікту, типового для будь-якої країни нового проживання переселенців, конфлікту між ними й суспільством, ними й урядом; позитивне вирішення боротьби для обох сторін, як приклад можливості цивілізованого розв'язання актуального питання, Канади та української діаспори як національної меншини; відбити й важливість та авторитетність громадянської позиції науковця, який відстоює принципи та інтереси власного народу, доводить свою етнічну невід`ємність від нього.

Викладення основного матеріалу. Пропонована стаття потребувала застосування таких наукових підходів, як: історико-порівняльний, системний, діяльнісний, діалоговий тощо. Так, системний підхід дозволив простежити взаємозв язок явищ, спричинених тенденцією українців-переселенців до мовної асиміляції і суспільних процесів в оточуючому діаспору англомовному середовищі Канади; вплив соціального середовища на образ мовної особистості іммігранта.

у контексті проблем конорліктизації, які притаманні поліетнічному середовищу будь-якої країни, мовний конфлікт між діаспорою та оточуючою мовною більшістю $€$ одним із соціальних конфрліктів. Він $€$ 
принциповим, оскільки від його розв'язання залежить збереження національної ідентичності, культури, мови імміграційної спільноти як гілки своєї історичної батьківщини. «Адже культурний світ українців $\epsilon$ визначальним чинником вираження ментальності й формуванню національної свідомості. Особливо це виявляється у людей, які з тих чи інших причин та через різні життєві ситуації опинилися за межами своєї батьківщини-емігрували до інших країн» [17, с. 253].

Проблеми етнічності діаспори розглянуто в працях таких дослідників різних поколінь, як: Б. Ажнюк, Л. Аза, О. Антонюк, М. Биховець, І. Варзар, С. Вдовенко, В. Євтух, Ю. Жлуктенко, О. Майборода, В. Макар, Л. Масенко, В. Наулко, О. Нельга, А. Попок, Р. Сіромський, Д. Струк, В. Трощинський, А. Шлепаков, П. Юзик та ін.

До дисциплін, В яких вивчається конфрлікт (конфліктологія, соціальна психологія, етносоціологія, комунікативістика, цивілізаціологія, українознавство, психолінгвістика, етнолінгвістика і т. д.) додамо соціолінгвоукраїністику, соціолінгвістику, мовознавство, оскільки розглядатимемо конфлікт лінгвістичної меншості та титульної англомовної більшості Канади через призму збереження мови української спільноти у цій країні. А це - понад 125 років, позначених боротьбою діаспори за свою національну ідентичність, складником чого є мова [16].

В історії української еміграції до Канади в науковій літературі виділяють чотири хвилі: перша - 3 кінця XIX ст. до Першої світової війни (піонерський період); друга - між двома світовими війнами; третя після Другої світової війни і четверта після здобуття Україною незалежності. Політологи порушують питання і про нову (п`яту) хвилю української еміграції У 19161970 рр. - українське шкільництво переживає період скасування двомовного навчання в державних освітніх закладах; третій - від 1971 р. -відновлюється двомовне навчання в системі державної освіти (вивчення української мови як навчальної дисципліни і викладання української мовою окремих шкільних предметів. Так, до 1897 р. українська мова в провінції Манітобі мала такі ж права, як і французька. Однак у 1897 р. ї̈ урядом було запроваджено акт-договір, що надавав привілеї двомовним школам (англо-французьким та англійським), а в 1916 р. було скасовано двомовні школи. Як мову викладання запроваджено англійську. Цей приховано лінгвіцидний період тривав у Манітобі майже півстоліття [16].

У піонерський період перебування перших українських поселенців у Канаді в майже неписьменного, малограмотного загалу трудової імміграції, спрацьовує феномен генної пам`яті. Відомий своїми новаторськими педагогічними підходами вчитель і громадський діяч Д.Прокоп узагальнював (прожив у Канаді майже 76 років): «То ж «чи не чудом треба уважати той фракт, що велика частина нашого народу, приїхавши сюди без власного політичного обличчя, аж тут, на чужій землі, у дуже несприятливих умовах, знайшла свою політичну ідентичність. Коли інші народи асимілювалися, поривали зв'язки з своєю мовою, культурою, а інколи навіть із своїми рідними, наш народ не тільки не цурався себе, своєї мови, своєї культури, своєї церкви і своїх традицій, він, наче по східцях, підіймався угору, до нової національної свідомості, навіть більше, він активно включився в боротьбу за права свого народу на рідних землях» $[13$, c. 19-20]».

Попри складнощі (брак учителів, узагалі інтелігенції, грамотних людей, підручників українською мовою для навчання дітей і т. д.), українською громадою за десятиліття будуються школи, бібліотеки, церкви, Народні доми. Постають видавництва, відкриваються книгарні; працюють недільні школи, активізуються тисячі творчих аматорських колективів. Невтомні зусилля до цього докладають комітети, спілки, союзи, благодійні фонди української діаспори. За цим стоять - тисячі ентузіастів, активістів, благодійників із простих сімей.

Другий період позначений тим, що в 1944 1945 рр. в Саскачеванському університеті було введено перший некредитований курс української мови, вечірня зміна. Восени 1945 р. - почали роботу кредитовані курси української мови, перші у канадському університеті, перші курси слов'янської мови у вищих школах країни.

Я. Рудницький переїхав до Канади в 1949 р. 3 Німеччини, тобто, під час другого періоду відстоювання українською діаспорою рідної мови. Це - третя хвиля української імміграції до Канади, що сталася після Другої світової війни, коли сюди переїхала значна кількість української інтелігенції,, зокрема, науковців. Ярослав Богдан Рудницький (1910-1995) - видатний вчений, мовознавець, славіст, фольклорист, бібліограф, бібліотекознавець, меценат, організатор української науки XX ст.; один із фундаторів Інституту славістики УВАН в Аугсбурзі (Німеччина, 1948 р.); профресор і голова відділу славістики у Манітобському університеті (Вінніпег, Канада, 1949-1977); видавець наукових серій "Славістика" (1949-1973рр.); президент УВАН (19551969), член Канадської федеральної Королівської комісії для справ двомовності й двокультурності (19681971 рр.). Він автор майже 3000 наукових праць. Одна $з$ лексикографічних, обсягом приблизно дві тисячі сторінок, - "Етимологічний словник української мови" (1962-1982) - належить до золотого фонду світової україністики $[15 ; 1 ; 2 ; 4 ; 3]$.

Уже за час проживання і роботи Я. Рудницького в Канаді в 1958-1959 рр. в Саскачеванському університеті запроваджується заочний курс української мови. Навчання української мови вводиться на четвертому курсі фрілософського відділу Університету Британської Колумбії (1965). Курс української мови в Манітобському університеті - в 1965 р. У 70-х роках у місцях найгустішого поселення українців було введено фракультативне навчання української мови: в середніх, пізніше - в початкових школах.

3 точки зору дотримання демократичності, - ніби все відрегульовано в країні й мовні права української спільноти не було порушено. Втім, до 1971 р. українська мова в Канаді не мала конституційних прав (у Канаді діє 
писана не кодифікована Конституція, тобто Основний закон країни складається не з одного, а з цілої серії актів, прийнятих у період з 1867 по 1982 р.). Законодавчо і нормативно права української мови в країні не було закріплено. Тобто, мовний конфлікт, проблема самовизначення нації в соціальному просторі (соціальна категорізація) залишалися нерозв язаними.

Однак у відстоюванні національної культури українців знаний учений не був «одним у полі воїном», як дехто визначав його власну політику [9]. Зокрема, письменник, журналіст, громадський діяч, автор шкільних підручників, відомий у Канаді своїми педагогічними ідеями вчитель Іван Боднарук визначав ситуацію з обмеженням уживання української мови і застосовував термін винародовлення (тобто, втрату ознак нації), вбачаючи у цьому загрозу мовної асиміляції [1]. Як настанови супроти мовного винародовлення українства розтлумачував біблійні заповіді митрополит Іларіон (Іван Огієнко), теж послуговуючися цим терміном, неодноразово і наполегливо публікуючи свої наукові та науковопубліцистичні статті з цього питання [7].

Етнолінгвістичний конфрлікт ми пропонуємо розглянути не тільки як позицію вченого й особистості, в даному разі Я. Рудницького, а й як протистояння обґрунтованої наукової позиції суспільній ситуації, думці громадськості титульної нації.

Я. Рудницький був піонером у вивченні міських українських діалектів у Канаді; в їх аналізі на фонетичному, лексичному, морфологічному, синтаксичному, структурних рівнях, у дослідженні мовно-правописної дійсності тощо; вивчав стан української мови й мовне питання в Манітобі, «канадизми» в поезії та інших художніх творах українських письменників Канади та ін. Отже, як учениймовознавець він мав підстави й аргументи, оскільки вони були науково обґрунтовані, на протистояння осріційній позиції уряду щодо стану, збереження і майбутнього розвитку української мови в Канаді. Дивимося, наприклад, його праці: Матеріяли до українсько-канадійської фролькльористики й діялектології. Т. 1 (Вінніпег: УВАН, 1956 (Збірник заходознавства; т. 3); Студії 3 назвознавства і слов'янський назовничий фольклор / УВАН (Onomastica. 1956. С. 1-31); Правописний словник української мови / Укр. Могиляно-Мазеп. Акад. Наук; Науково-дослід. т-во укр. термінології ; за ред. Я. Рудницького і К. Церкевич. Монреаль: [б. в.], 1979 (Обсяг «Словника» - близько 65 тис. слів); Studies in onomastics. Vol. 2. Toponymy (Winnipeg: Publ. by Ukrainian Free Acad. of Sciences, 1958. (Onomastica; №15 До 100-річчя української мови в Манітобі (Західньоканадський збірник. Ч. 2 / Канад. НТШ (Едмонтон: Гомін України, 1975 / Канад. НТШ, Осередок на Західню Канаду; т. 17).)) До історії української меншості в Канаді. 1967-1987 // Укр. історик. - 1987. №1/4. - С. 119-124 і т. д. У 1990 р. на Міжнародному конгресі мовознавства було оприлюднено зміст доповіді Я. Рудницького "Еволюція слов янської двомовної лексикографії: українські двомовні словники від 1596 року", що мала значний розголос у фахівців з мовознавства, лексикографії та українознавства [10].

Хоча українська мова в Канаді урядами провінцій країни не переслідувалася, не заборонялася, справа іiї збереження була і залишається справою української спільноти. Я. Рудницький як науковець усвідомлював загрозу втрати нею в Канаді власної мови як складника національної ідентичності, а, отже, й розчинення етносу в англомовному середовищі та поповнення його обсягу.

Перед нами дві сторони соціального конфлікту зацікавлений у залученні нових громадян до своєї країни канадський уряд, з іншого боку - солідний учений-українець, який має високий суспільний і науковий імідж, сотні праць і ризикує через своє протистояння офріційній точці зору і принципову громадянську позицію втратити цей імідж. Мовний конфлікт національної меншості, лінгвістичної меншості, піднімався до категорії соціальної проблеми.

Королівською комісією з двомовності (Royal Commission on Bilingualism and Biculturalism) (1963-1970 pp.) було започатковано політику офріційних мов і багатокультурності [9].

П'єр Еліот Трюдо, в 1968 р. прем'єр-міністр країни, подав до парламенту Закон про офріційні мови (Official Languages Act), який було схвалено в 1969 р. у парламенті Канади (уточнення робилися в 1982 р. та в 1988 р.). У 1969 р. було оприлюднено рекомендацій до "Мовного Акту" Королівської комісії двомовності та двокультурності, який проголошував англійську і французьку мови офріційними по всій території Канади, що сприяло уникненню національних суперечок між етнічними групами в країні. Акт встановлював рівність англійської та фрранцузької мов як у парламенті та уряді, так і в канадському суспільстві. 7 вересня 1969 р. вступив у силу Закон про офіційні мови в Канаді. Створюється Комісія з двокультурності і двомовності. Згідно з Конституцією Канади 1980 р. у країні мала бути дотримана офріційна рівність між англійською та французькою мовами. За дотримання Акту про офріційні мови відповідальність було покладено на федеральні органи виконавчої та законодавчої влади [12]. Провінційні акти визначають можливість вивчення другої мови в Канаді. Найвищий орган управління Рада Міністрів освіти Канади. Діє децентралізована система освіти. На урядовому рівні - Програма розвитку офіційних мов меншин Development of OfficialLanguage Communities Program. У 1971 р. було запроваджено Програму багатокультурності [24]. Це був розважливий крок канадського уряду. Йдеться про спеціальний режим захисту мов, під чим розуміється надання меншинам додаткових прав. Канадський Акт «Про багатокультурність» увібрав у себе ряд соціокультурних і етносоціологічних пунктів. У «Преамбулі» до Акту «Про багатокультурність» відбито громадські, політичні, соціальні, мовні права, закріплені Конституцією Канади [14]. Багатокультурність відіграє роль соціальної інтеграції держави, головним завданням якої $\epsilon$ розвиток культурних систем, достойний розвиток культур національних меншин.

Утім, залишалися деякі проблеми стосовно цих 
іммігрантських спільнот, зокрема, української. Тому Я. Рудницький продовжує відстоювати конституційне визнання рідної мови в Канаді [5]. Насамперед, 3 позицій лінгвістики, мовознавчих дисциплін підходив він до розв'язання конфліктної проблеми. Саме ним запроваджено у науковий і широкий суспільний обіг дефініцію - лінгвоцид (від лат. lingua - мова, caedere знищення; «linguicide» (кальк. «лінгвіцид»)) [19; 21; 23; 20] - лінгвоцид (мововбивство), що $€$ проекцію конфрлікту латентного, але цілеспрямованого поглинання одного народу іншим, національного нівелювання та збіднення культур і призводить до деградації світової цивілізації взагалі, розриву національних зв'язків 3 історичною батьківщиною, мовної асиміляції.

Лінгвоцид - це боротьба між загарбницькими імперськими поглядами й якимсь конкретним народом, який підлягає, з точки зору загарбника, не фрізичному знищенню, а поступовому поповненню статистичних показників зростання населення імперії; це - конфрлікт культур, ментальностей і т. Д., гострота чого має тенденцію набути критичної маси й може сягнути відкритих воєнних дій, чому є приклади в світовій історії.

Лінгвоцид у країнах нового проживання переселенців має інші причини й іншу природу, але $є$ небезпечним для збереження рідної мови й національної ідентичності переселенців. Його жодним чином не можна плутати 3 інтерференцією мов, об єктивним явищем впливу однієї мови на іншу. I хоч як би там не було, мовна інтерференція не повинна набути форм лінгвоциду. Я. Рудницький як мовознавець, фольклорист усвідомлював проблемність ситуації, яка для української діаспори Канади дедалі набувала форми конфрлікту. Вчений містким, узагальнюваним терміном - лінгвоцид уперше в науці позначив будь-які спроби суспільства чи державних інституцій, офіційної влади обмежити або підтримати використання однієї мови за рахунок іншої і тим самим знищити націю як окремішність культури В цивілізаційному просторі. Пізніше про жорстокість, відвертість, закамуфрльованість і різноманіття форм лінгвоциду напише П. Кононенко [8].

У 1968 р. Я. Рудницьций висуває пропозицію прогошення Організацією Об`єднаних Націй п`ятої свободи, а саме свободи від усіх проявів мовного поневолення й лінгвоциду та встановлення перманентної інституції при ООН для протидії всім заходам у справі лінгвоциду [18]. У тому ж році Я. Рудницький подає рапорт й окремі рекомендації Королівської комісії двомовності та двокультурності [5].

Свої висновки Я. Рудницький узагальнює в праці, що є третім переробленим виданням: «Linguicide. Third Revised Edition Ukrainian Technological Univ. (Winnipeg; Munich: [б. в.], 1976), де проаналізує лінгвоцидні акції та модифікації лінгвоциду і виробляє рекомендації з їх запобігання та усунення цих проявів нецивілізованості. Учений розглядає канадські урядові постанови й документи щодо двомовності, здійснює їх історико-політологічний аналіз з точки зору подальшого вільного розвитку української мови. Він досліджує природу багатомовності, відпрацьовує концепцію двомовності в її широкому застосуванні (тобто, включаючи колоніальний аспект) [24].

Свою позицію професор виклав і в статті «Cultures in Contact» («Культури в контакті») [22]. Він пішов на конфрлікт з урядом і зумів розв язати його мудро, позитивно, толерантно, від чого виграли обидві сторони суперечки: й українська діаспора, й Канада. Більше того, концептуальне узагальнення канадськоукраїнського вченого було підтримано його колегами і однодумцями з історичної батьківщини, які визначили цим терміном кількастолітній імперський тиск, спрямований на знищення української мови.

Л. Гапон у кандидатській дисертації «Лінгвістина спадщина Ярослава-Богдана Рудницького (Тернопіль, 2017) справедливо зауважує, що вивчення внеску Я. Рудницького в українську лінгвістику тільки починається. Ми наголосимо, що потребує спеціального дослідження внесок цього видатного вченого і в канадсько-українську соціолінгвістику та етнолінгвістику.

У передмові до монографії «Українська мова у XX сторіччі: історія лінгвоциду. Документи і матеріали / за ред. Л. Масенко. Київ: Вид. дім Києво-Могилянська академія. 2005)» проф. Л. Т. Масенко відбиває історію лінгвоциду в УРСР. Н. В. Тумай розглядає лінгвоцид як політику нищення мов у дисертаційному дослідженні на здобуття наукового ступеня кандидата фрілологічних наук «Лінгвоцид української мови та шляхи його подолання українством у XIX - на початку XX ст.» (Київ. нац. ун-т ім. Тараса Шевченка, 2006). Явище лінгвоциду в історії української літературної мови (XVII- XIX ст.) досліджують Л. Мацько та В. Христенок (Укр. мова. К. 2003. №2. С. 58) та ін., Радевич-Вінницький розглядає лінгвоцид як форму геноциду (Київ : Укр. вид. спілка ім. Ю. Липи, 2011) та ін.

Якщо ми перегорнемо сторінки української історії та науки, то переконаємося, що Я. Рудницький був не єдиним ученим, який відстоював свої громадянські та наукові принципи, вступаючи в соціальний конфлікт 3 офріційною владою. В.І. Вернадський поїхав у розташування ставки Денікіна, щоб захистити ідею фундації Української академії наук. Сотні українських науковців за часів радянської влади залишилися без роботи, без можливості друкувати свої наукові праці, часто, й без засобів до існування: М. Брайчевський, Олена Апанович, Олена Компанець, Я. Дашкевич, Я. Дзира, І. Дзюба, І. Шовкопляс та ін.; сотні представників української інтелігенції змушені були з причини несприйняття імперської політики i, зокрема, мовної, радянського уряду на знак протесту проти неї іммігрувати за кордон, шукати прихистку в інших землях.

Висновок. Наукове пізнання, а його предметом була мовна ситуація, в якій перебувала українська діаспора, дало результат: розв язання лінгвістичного конфлікту в Канаді. Аналіз суспільної діяльності вченого Я. Рудницького стимулює переосмислення проблеми етнолінгвістичної інтеграції представників української діаспори, якій удалося зберегти свою національну інтеграцію у канадський етнопростір, проблеми 
формування мовної особистості і мовного образу особистості українського іммігранта в Канаді; доводить важливість позиції авторитетного вченого, який може і має можливість донести свою думку до офріційних кіл, що змушені рахуватися з нею, дослухатися ії, оскільки мають справу з відомим ученим. Підсумовуючи, можемо зробити висновок, що дії Я. Б. Рудницького з метою надання конституційних прав українській мові в Канаді, по суті, є моделлю одержання етнолінгвістичного компромісу.

1. БоднарукІ. Наша молодь під загрозою винародовлення. Життя і школа. 1962. Частина 1/3. С. $1-4$.

2. Дзира Я. Пошануймо свою славу: ЯрославБогдан Рудницький - учений, патріот. Пам'ятки України: історія й культура. 1999. №1. С. 145-157.

3. Дегтяренко Л. Міжнародний науковий симпозіум: «Ярослав Богдан Рудницький - видатний український мовознавець, славіст, педагог, видавець» (17 серп. 2001 р.). Бібліотечний вісник. 2001. №6. С. 7-11.

4. Домбровський О. Ярослав Богдан Рудницький. Український історик. 1995. №1/4. С. 321-324.

5. За Конституційне визнання української мови в Канаді: рапорт Королівської комісії для справ двомовности й двокультурности в Канаді й окремі рекомендації проф. Я. Рудницького. Жіночий світ. Вінніпег, 1968. №1. 7с.

6. І один у полі воїн. Rudnyckiana. №4 / Ukrainian Language Association. Ottawa: [б. в.], 1988. Р. 21-36.

7. Іларіон. Десять рідномовних заповідей для емігранта. Життя і школа. 1991. №3. 13 с.

8. Кононенко П. Десять років шляхом розвитку українознавства як цілісної науки і освітньої дисципліни. Українознавство - наука самопізнання українського народу: матеріали X-ї щорічної Міжнародної науковопрактичної конференції 18-20 жовт. 2001 р. Київ: НДІУ, 2001. 7 c.

9. Мета політики Канадського уряду щодо багатокультурности. Жіночий світ. Торонто, 1973. Ч. 3. $17 \mathrm{c}$.

10. Носко-Оборонів Т. На Міжнародному конгресі мовознавства. Око світу. 1990. Частина 5. 41 с.

11. Носко-Оборонів Т. Ярослав-Богдан Рудницький. Ottawa: Ukrainian Language Association, 1984. 48 с. (Біобібліогр. / Українська Могилянсько-Мазепинська академія наук; частина 5).

12. Офріційний мовний акт (The Official Languages Act), Канадський Статут Прав і Свобод / Departament of Yustice Canada. Way of access. URL: http://laws.justice.gc.ca/en/O-3/01/

13. Прокоп Д. Українці в Західній Канаді. До історії їхнього поселення та поступу. Едмонтон. Вінніпег Print. by Trident Press Ltd, 1983. $547 \mathrm{c}$.

14. Сіромський P. Питання багатокультурності та збереження національної ідентичності канадських українців у дослідженнях Ярослава Рудницького. URL: http://dspace.nbuv.gov.ua/bitstream/handle/123456789/129 94/24-Siromsky.pdf?sequence $=1$.

15. СлавутичЯ. Творець української науки в Канаді та інші статті й матеріяли з приводу 60-річчя проф. Я. Рудницького. Вінніпег: Фундація ім. Д. ЛОБАЯ, 1971. 96 c.

16. Солонська Н., Борисович Г. Українська канадіана: анотований покажчик видань 3 фонду Національної бібліотеки України ім. В. І. Вернадського / наук. ред. Г. Ковальчук; К. Лобузіна (комп`ютерна технологія; НАН України, НБУВ. Київ: НБУВ, 2017. 171 с.

17. Сорочук Л. Етнокультурна традиція українства у контексті світового культурного простору. Українознавчий альманах, 2015. Випуск 18. С. 252-257.

18. РудницькийЯ.До проблеми мововбивства (лінгвоциду). Збірник наукових праць на пошану Євгена Вертипороха, президента Головної Ради Наукового товариства імені Шевченка і Голови Канадського НТШ з нагоди 70-річчя його життя,1972. С. 95-100.

19. Рудницький Я. Лінгвіцид. Вінніпег; Мюнхен, 1976. 31 c.

20. Rudnyckyj J. B. An Etymological dictionary of the Ukrainian Language. Chap. 2. Winnipeg: Ukrainian Free Academy of Sciences, 1963. 192 p.

21. Rudnyckyj J. B. Classification of Canadian placenames. Quatrième congrès international de sciences onomastiques. Uppsala: [б. в.], 1952. P. 453-457.

22. Rudnyckyj J. B. Cultures in Contact. Slavic Studies. Випуск 25. 1949-1974. Winnipeg: [б. в.], 1974. C. 211-213.

23. Rudnyckyj J. Languages of Canada. Ottawa; Montreal: [б. B.], 1987.86 p.

24. Rudnyckyj J. B. Multiculturalism and multilingualism in Canadan. Ottawa, Ontario: Ukrainian Language Association, 1983. 84 p.

\section{Reference}

1. Bodnaruk I. (1962). Nasha molod pid zahrozoiu vynarodovlennia [Our youth is under threat of denationalization] Zhyttia i shkola. Chastyna 1/3. P. 1-4. (in Ukrainian).

2. Dzyra Ya. (1999). Poshanuimo svoiu slavu: Yaroslav-Bohdan Rudnytskyi - uchenyi, patriot [Let's honor our glory: Yaroslav-Bohdan Rudnytsky is a scientist, a patriot] Pamiatky Ukrainy: istoriia y kultura. №1. P. 145157. (in Ukrainian).

3. Dehtiarenko L. (2001). Mizhnarodnyi naukovyi sympozium: "laroslav Bohdan Rudnytskyi - vydatnyi ukrainskyi movoznavets, slavist, pedahoh, vydavets" (17 serp. 2001 r.) [International Scientific Symposium: "Yaroslav Bohdan Rudnytsky - an outstanding Ukrainian linguist, Slavic scholar, teacher, publisher"(Aug. 17, 2001).] Bibliotechnyi visnyk. №6. P. 7-11. (in Ukrainian).

4. Dombrovskyi O. (1995). Yaroslav Bohdan Rudnytskyi [Yaroslav Bohdan Rudnytsky] Ukrainskyi istoryk. №1/4. P. 321-324. (in Ukrainian).

5. Za Konstytutsiine vyznannia ukrainskoi movy $v$ Kanadi: raport Korolivskoi komisii dlia sprav dvomovnosty y dvokulturnosty $v$ Kanadi y okremi rekomendatsii prof. Ya. Rudnytskoho. Zhinochyi svit. (1968). [For the Constitutional Recognition of the Ukrainian Language in Canada: Report of the Royal Commission for Bilingualism and Biculturalism in Canada and Selected Recommendations of Prof. J. Rudnytsky] Vinnipeh. №1. P. 7. (in Ukrainian). 
6. I odyn u poli voin. (1988). [And one warrior in the field] Rudnyckiana. №4 / Ukrainian Language Association. Ottawa: [b. v.]. P. 21-36. (in Ukrainian).

7. Ilarion. (1991). Desiat ridnomovnykh zapovidei dlia emihranta [Ten native commandments for the emigrant]. Zhyttia i shkola. №3. P. 13. (in Ukrainian).

8. Kononenko P. (2001). Desiat rokiv shliakhom rozvytku ukrainoznavstva yak tsilisnoi nauky i osvitnoi dystsypliny [Ten years through the development of Ukrainian studies as a holistic science and educational discipline]. Ukrainoznavstvo - nauka samopiznannia ukrainskoho narodu: materialy $\mathrm{X}$-yi shchorichnoi Mizhnarodnoi naukovo-praktychnoi konferentsii 18-20 zhovt. 2001 r. Kyiv: NDIU. P. 7 (in Ukrainian).

9. Meta polityky Kanadskoho uriadu shchodo bahatokulturnosty [The purpose of the Canadian government's policy on multiculturalism. Women's world.]. (1973). Zhinochyi svit. Toronto. Ch. 3. P. 17. (in Ukrainian).

10. Nosko-Oboroniv T. (1990). Na Mizhnarodnomu konhresi movoznavstva [At the International Congress of Linguistics]. Oko svitu. Chastyna 5. P. 41. (in Ukrainian).

11. Nosko-Oboroniv T. (1984). Yaroslav-Bohdan Rudnytskyi [Yaroslav-Bohdan Rudnytsky]. Ottawa: Ukrainian Language Association. 48 p. (Biobibliohr. / Ukrainska Mohyliansko-Mazepynska akademiia nauk; chastyna 5). (in Ukrainian).

12. Ofitsiinyi movnyi akt [The Official Languages Act], Kanadskyi Statut Prav i Svobod [Canadian Charter of Rights and Freedoms] / Departament of Yustice Canada. Way of access. URL: http://laws.justice.gc.ca/en/O-3/01/ (in Ukrainian).

13. Prokop D. (1983). Ukraintsi v Zakhidnii Kanadi. Do istorii yikhnoho poselennia ta postupu [Ukrainians in Western Canada. To the history of their settlement and progress]. Edmonton. Vinnipeh Print. by Trident Press Ltd. 547 p. (in Ukrainian).

14. Siromskyi R. Pytannia bahatokulturnosti ta zberezhennia natsionalnoi identychnosti kanadskykh ukraintsiv u doslidzhenniakh Yaroslava Rudnytskoho [Issues of multiculturalism and preservation of the national identity of Canadian Ukrainians in Yaroslav Rudnytsky's research] URL: http://dspace.nbuv.gov.ua/bitstream/handle/123456789/129 94/24-Siromsky.pdf?sequence=1. (in Ukrainian).
15. Slavutych Ya. (1971). Tvorets ukrainskoi nauky v Kanadi ta inshi statti y materiialy z pryvodu 60-richchia prof. Ya. Rudnytskoho [The creator of Ukrainian science in Canada and other articles and materials on the occasion of the 60th anniversary of Prof. J. Rudnytsky]. Vinnipeh: Fundatsiia im. D. LOBAla. 96 p. (in Ukrainian).

16. Solonska N., Borysovych H. (2017). Ukrainska kanadiana: anot. pokazh. vydan z fondu Natsionalnoi biblioteky Ukrainy im. V.l. Vernadskoho [Ukrainian Canadian: annotated index of publications from the collection of the National Library of Ukraine. V. I. Vernadsky] / nauk. red. H. Kovalchuk; K. Lobuzina (komp iuterna tekhnolohiia; NAN Ukrainy, NBUV. Kyiv: NBUV. 171 p. (in Ukrainian).

17. Sorochuk L. (2015). Etnokulturna tradytsiia ukrainstva u konteksti svitovoho kulturnoho prostoru. [Ethnocultural tradition of Ukrainians in the context of the world cultural space]. Ukrainoznavchyi almanakh. Vypusk 18. P. 252-257. (in Ukrainian).

18. Rudnytskyi Ya. (1972). Do problemy movovbyvstva (linhvotsydu) [To the problem of language murder (linguocide)]. Zbirnyk naukovykh prats na poshanu Yevhena Vertyporokha, prezydenta Holovnoi Rady Naukovoho tovarystva imeni Shevchenka i Holovy Kanadskoho NTSh z nahody 70-richchia yoho zhyttia. P. 95-100. (in Ukrainian).

19. Rudnytskyi Ya. (1976). Linhvitsyd [Linguisticide]. Vinnipeh; Miunkhen. 31 p. (in Ukrainian).

20. Rudnyckyj J. B. (1963). An Etymological dictionary of the Ukrainian Language. Chap. 2. Winnipeg: Ukrainian Free Academy of Sciences. 192 p.

21. Rudnyckyj J. B. (1952). Classification of Canadian place-names. Quatrième congrès international de sciences onomastiques. Uppsala: [b. v.]. P. 453-457.

22. Rudnyc'kyj J. B. (1974). Cultures in Contact. Slavic Studies. Vypusk 25. 1949-1974. Winnipeg: [b. v.]. P. 211-213.

23. Rudnyc'kyj J. (1987). Languages of Canada. Ottawa; Montreal: [b. v.]. 86 p.

24. Rudnyckyj J. B. (1983). Multiculturalism and multilingualism in Canadan. Ottawa, Ontario: Ukrainian Language Association. $84 \mathrm{p}$. 